


\section{Indampen van dunne mestfracties in combinatie met een luchtwasser}

P. Hoeksma, A. Hol, R. Verheijen, N. Verdoes

Dit onderzoek is uitgevoerd door Wageningen Livestock Research, in opdracht van en gefinancierd door voormalig Productschap voor Vee en Vlees en het Ministerie van Economische Zaken.

Wageningen Livestock Research

Wageningen, februari 2017

Rapport 1014 
P. Hoeksma, A. Hol, R. Verheijen, N. Verdoes 2016. Indampen van dunne mestfracties in combinatie met een luchtwasser; Wageningen Livestock Research, Rapport 1014.

\section{Samenvatting NL}

Indikken van dunne mestvloeistof in een indamper/luchtwasser combinatie, waarbij gebruik wordt gemaakt van geventileerde stallucht, kan een aanzienlijke volumereductie opleveren zonder dat dit ten koste gaat van de emissiereducerende werking van de luchtwasser voor wat betreft ammoniak en geur. Op een zeugenbedrijf kan het mestvolume minimaal met een derde worden gereduceerd. De kosten van de volumereductie bedragen ongeveer 12 euro per $\mathrm{m}^{3}$.

\section{Summary UK}

The effect of an evaporator/air-scrubber combination on the reduction of ammonia and odour was evaluated and the evaporation capacity was assessed.

It was concluded that at pig farms substantial reduction (one third) of the slurry volume can cost effectively be achieved while maintaining ammonia and odour reduction effiency.

Dit rapport is gratis te downloaden op http://dx.doi.org/10.18174/407912 of op www.wur.nl/livestock-research (onder Wageningen Livestock Research publicaties).

\section{(C) 2016 Wageningen Livestock Research}

Postbus 338, 6700 AH Wageningen, T 03174839 53, E info.livestockresearch@wur.nl, www.wur.nl/livestock-research. Wageningen Livestock Research is onderdeel van Wageningen University \& Research.

Wageningen Livestock Research aanvaardt geen aansprakelijkheid voor eventuele schade voortvloeiend uit het gebruik van de resultaten van dit onderzoek of de toepassing van de adviezen.

Alle rechten voorbehouden. Niets uit deze uitgave mag worden vermenigvuldigd en/of openbaar gemaakt worden door middel van druk, fotokopie, microfilm of op welke wijze dan ook zonder voorafgaande toestemming van de uitgever of auteur. onderzoeksopdrachten zijn de Algemene Voorwaarden van de Animal Sciences Group van toepassing. Deze zijn gedeponeerd bij de Arrondissementsrechtbank Zwolle. 


\section{Inhoud}

$\begin{array}{ll}\text { Samenvatting } & 5\end{array}$

1

$\begin{array}{ll}\text { Inleiding } & 6\end{array}$

2

$\begin{array}{ll}\text { Materiaal en methoden } & 7\end{array}$

$\begin{array}{lll}2.1 & \text { Oriëntatiefase } & 7\end{array}$

2.1.1 Meetlocaties 7

2.1.2 Metingen en waarnemingen $\quad 10$

2.2 Meetfase 10

2.2.1 Meetlocatie 10

2.2.2 Meetprogramma 11

$\begin{array}{llr}3 & \text { Resultaten } & 12\end{array}$

3.1 Oriëntatiefase $\quad 12$

3.1 .1 Bedrijf A 12

$\begin{array}{ll}3.1 .2 \text { Bedrijf } B & 13\end{array}$

$\begin{array}{ll}3.1 .3 \text { Bedrijf C } & 14\end{array}$

3.2 Meetfase 16

3.2.1 Volume en samenstelling processtromen 16

$\begin{array}{ll}3.2 .2 \text { Verbruik hulpstoffen } & 18\end{array}$

$\begin{array}{ll}3.2 .3 \text { Ammoniak en geur } & 19\end{array}$

$\begin{array}{ll}3.2 .4 \text { Flowschema } & 20\end{array}$

$\begin{array}{ll}3.2 .5 \text { Economie } & 20\end{array}$

4 Discussie en conclusie $\quad 21$

$\begin{array}{lll}4.1 & \text { Discussie } & 21\end{array}$

$\begin{array}{lll}4.2 & \text { Conclusie } & 22\end{array}$

$5 \quad$ Literatuur $\quad 23$

$\begin{array}{lll}\text { Bijlage } 1 \text { Verwachte emissies -theoretische beschouwing } 24 & 24\end{array}$ 



\section{Samenvatting}

Luchtwassers kunnen worden ingezet voor het indikken van dunne mestfracties, met behoud van de werking en het rendement van de luchtwasser. Gangbare luchtwassers kunnen op verschillende manieren worden toegepast in combinatie met indampen, waarbij gebruik wordt gemaakt van geventileerde stallucht. De technische en economische haalbaarheid van dit concept is onderzocht in een gefaseerd meetproject op praktijkschaal. In de eerste fase zijn op drie varkensbedrijven oriënterende metingen uitgevoerd aan luchtwas/indamp installaties om een indruk te krijgen van de volumereductiepotentie van de installaties. In de tweede projectfase is aan één installatie een meetprogramma uitgevoerd waarbij gegevens zijn verzameld over de indampcapaciteit en het verbruik van energie en hulpstoffen. Tevens is van deze installatie het verwijderingsrendement van ammoniak en geur vastgesteld.

De resultaten laten zien dat indampen van dunne mestvloeistof in een indamper/luchtwasser combinatie, waarbij gebruik wordt gemaakt van geventileerde stallucht, een aanzienlijke volumereductie kan opleveren zonder dat dit ten koste gaat van de werking van de luchtwasser voor wat betreft reductie van ammoniak en geur. Op een zeugenbedrijf kan het mestvolume minimaal met een derde worden gereduceerd. De kosten van de volumereductie worden berekend op ongeveer $€ 12$,- per $\mathrm{m}^{3}$. 


\section{$1 \quad$ Inleiding}

In de varkenshouderij zijn de laatste jaren op een groot aantal varkensbedrijven (naar schatting circa $30 \%$ van de bedrijven) luchtwassers in gebruik genomen om emissies van ammoniak en geur uit stallen te verminderen. Uit onderzoek en uit praktijkervaringen van varkenshouders blijkt, dat via luchtwassers grote hoeveelheden water verdampt kunnen worden (Wagenberg et al., 1999; Melse en Ploegaert, 2011). Bij vleesvarkens is dit 400 liter water per dierplaats per jaar, wat overeenkomt met $35 \%$ van het mestvolume en bij kraamzeugen 1500 liter per dierplaats per jaar, wat gelijk is aan 25 tot $30 \%$ van het mestvolume. Hieruit is bij een groep varkenshouders het idee ontstaan om de luchtwasser in te zetten voor het indikken van dunne mestfracties, bijvoorbeeld verkregen na mechanische scheiding, na flotatie, na omgekeerde osmose etc., met behoud van de werking van de luchtwasser. Gangbare luchtwassers kunnen hiervoor op verschillende manieren worden ingezet. Op enkele varkensbedrijven zijn reeds op kleine schaal experimenteren en oriënterende metingen uitgevoerd. De resultaten waren veelbelovend zowel ten aanzien van de werking van de luchtwassers (reductie van geur, ammoniak en fijnstof) als de capaciteit voor reductie van mestvolume.

Berekeningen vooraf naar de haalbaarheid van dit systeem lieten zien, dat op varkensbedrijven de afzetkosten met bijna $€ 4$,- per $\mathrm{m} 3$ geproduceerde mest kunnen dalen. Dit toont aan dat het systeem in potentie ook financieel perspectieven biedt. Het concept van inzet van bestaande luchtwassers voor mestvolumereductie dient verder ontwikkeld en geoptimaliseerd te worden.

In de eerste fase van het ontwikkelings- en optimalisatietraject zijn op drie varkensbedrijven oriënterende metingen uitgevoerd aan luchtwas/indamp installaties om een indruk te krijgen van de volumereductiepotentie van de installaties. In de tweede projectfase is aan één installatie een meetprogramma uitgevoerd waarbij gegevens zijn verzameld over de indampcapaciteit en het verbruik van energie en hulpstoffen en waarbij tevens het verwijderingsrendement van ammoniak en geur van luchtwassers met voorgeschakelde indampsystemen is vastgesteld, zodat aan dergelijke combinaties een emissiefactor gekoppeld kan worden door de Tac-Rav. 


\section{Materiaal en methoden}

\subsection{Oriëntatiefase}

\subsubsection{Meetlocaties}

In de oriëntatiefase werden op de volgende bedrijven metingen uitgevoerd:

1. Bedrijf $A$

Dit vermeerderingsbedrijf (1200 zeugen) heeft een mestbewerkingsinstallatie waarin mest wordt gescheiden in een dikke en dunne fractie. De dikke fractie wordt in een vijzelpers verder ontwaterd. De dunne fractie van de zeefbandpers en de vijzelpers wordt behandeld middels air flotation onder toevoeging van een vlokmiddel en vervolgens beluchting, tot de dunne mestvloeistof waarmee de indampinstallatie wordt gevoed. Het bedrijf beschikt over twee luchtwassers (Inno+); een chemische wasser die de ventilatielucht van de zeugenstal behandelt en een combiwasser voor behandeling van de ventilatielucht van de stal met gespeende biggen (6000 dieren). Het maximale ventilatiedebiet van de zeugen- en biggenstal bedraagt respectievelijk 240.000 en 150.000 m3/uur. Voor de chemische wasser zijn twee indampunits geplaatst en voor de combiwasser één indampunit. Figuur 1 toont een schematische weergave van het luchtwas/indamp systeem.

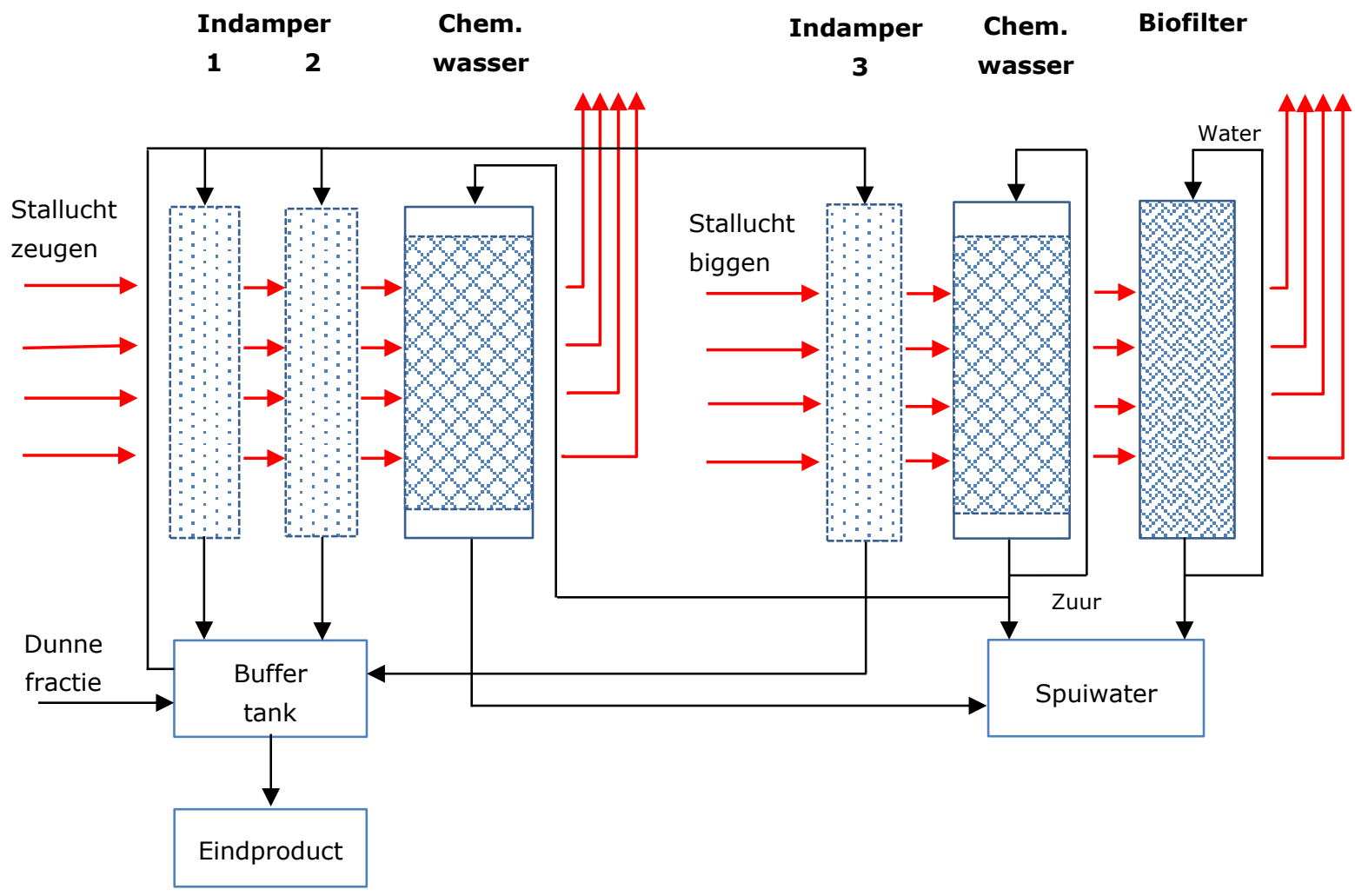

Figuur 1 Schematische weergave van het luchtwas/indamp systeem op bedrijf A.

De indampunits bestaan elk uit een 0,25 m dik pakket kunststofelementen (2H NET-filter), gelijk aan het vulpakket van de chemische wassers. De vulling van het biofilter bestaat uit houtkrullen.

De stallucht wordt er vanaf de zijkant doorheen geblazen (dwarsstroomprincipe) en gaat vervolgens door de wassers. Dunne fractie wordt van bovenaf over indampers gesproeid vanuit een buffertank. Dit gebeurt in een recirculerend proces totdat de vloeistof een bepaalde concentratie heeft bereikt, waarna deze als eindproduct wordt opgeslagen en afgevoerd. 
De concentratie wordt bepaald aan de hand van de geleidbaarheid. De capaciteit van de indampers bedraagt circa $1000 \mathrm{~m}^{3}$ dunne fractie per jaar. Tijdens het indampproces wordt ammoniak uit de dunne fractie gestript en met de lucht naar de wassers gevoerd. De chemische wassers krijgen op deze wijze extra ammoniak te verwerken, wat van invloed is op het zuurverbruik en het ammoniumgehalte van het spuiwater. Tabel 1 vermeldt per luchtwasser het aantal dieren dat wordt bediend en een schatting van het maximale ventilatiedebiet.

Tabel 1 Geïnstalleerde ventilatiedebiet en aantal dieren waarvan de lucht wordt behandeld per luchtwasser op bedrijf $A$.

\begin{tabular}{llrr}
\hline Luchtwasser & Dieren & Aantal & $\begin{array}{r}\text { Ventilatiedebiet } \\
\left(\mathrm{m}^{3} / \mathrm{h}\right)\end{array}$ \\
Chem. Wasser/biofilter & Biggen & 6000 & 150.000 \\
\hline Chem. Wasser & Zeugen & 1200 & 240.000
\end{tabular}

\section{Bedrijf $B$}

Dit is een bedrijf met 1000 zeugen, 3000 biggen en 3700 vleesvarkens. Er wordt geen mestvloeistof van het eigen bedrijf verdampt. Dunne fractie, verkregen na mechanische scheiding (zeefbandpers) en flotatie, wordt aangevoerd van een loonbedrijf dat varkensmest van derden verwerkt. De dunne fractie (5000 ton/jaar) wordt gebruikt als wasvloeistof in 7 chemische luchtwassers (fabrikaat Inno+). Hiervoor wordt aan de dunne fractie zuur toegevoegd. Figuur 2 toont een schematische weergave van het luchtwas/indamp systeem.



Figuur $2 \quad$ Schematische weergave van het luchtwas/indamp systeem op bedrijf B.

De 7 luchtwassers (met 0,4 m waspaketten (2H NET-filter), dwarsstroomprincipe), functioneren als zelfstandige eenheden, elk met een eigen ingaande en uitgaande luchtstroom. Ze behandelen de ventilatielucht van twee stallen. Tabel 2 vermeldt per luchtwasser het aantal dieren dat wordt bediend en een schatting van het maximale ventilatiedebiet.

Tabel 2 Geïnstalleerde ventilatiedebiet en aantal dieren waarvan de lucht wordt behandeld per luchtwasser op bedrijf $B$.

\begin{tabular}{rlrr}
\hline Luchtwasser nr. & Dieren & $\begin{array}{r}\text { Aantal } \\
\text { Ventilatiedebiet } \\
\left(\mathrm{m}^{3} / \mathrm{h}\right)\end{array}$ \\
\hline 8 & Vleesvarkens & 980 & 70.000 \\
\hline 2 & Vleesvarkens & 1175 & 82.500 \\
\hline 3 & Biggen & 3000 & 75.000 \\
\hline 4 & Zeugen & 500 & 10.000 \\
\hline 5 & Vleesvarkens & 1560 & 110.000 \\
\hline 6 & Zeugen & 500 & 10.000 \\
\hline 7 & Zeugen/Vleesvarkens & $350 / 780$ & 125.000
\end{tabular}




\section{Bedrijf C}

Dit bedrijf houdt circa 2000 vleesvarkens en 13.500 gespeende biggen. De mestproductie bedraagt circa 10.000 ton per jaar. De mest wordt op het bedrijf verwerkt tot 2500 ton dikke fractie, 5000 ton mineralenconcentraat (na omgekeerde osmose) en 7500 ton water. Het bedrijf beschikt over een luchtwas/indamp systeem waarmee de ventilatielucht van een stal met 720 vleesvarkens en 3500 biggen wordt behandeld en een derde deel (1500 ton) van het geproduceerde mineralenconcentraat wordt ingedampt. Het luchtwas/indamp systeem bestaat uit een indampunit en een combiwasser (combinatie van chemische wasser en biofilter). Figuur 3 toont een schematische weergave van het luchtwas/indamp systeem.



Figuur 3 Schematische weergave van het luchtwas/indamp systeem op bedriff $C$.

De indampunit bevat een $0,25 \mathrm{~m}$ dik vulpakket van kunststofelementen (vlakfolie pakket), gelijk aan het waspakket van de chemische wasser. Het biofilter is gevuld met houtkrullen. De stallucht wordt er vanaf de zijkant doorheen geblazen (dwarsstroomprincipe) en gaat vervolgens door de wasser. Mineralenconcentraat wordt van bovenaf recirculerend vanuit een buffertank over de indamper gesproeid totdat het concentraat een bepaalde geleidbaarheid heeft bereikt. Ammoniak, die uit het mineralenconcentraat wordt gestript, wordt met de stallucht meegevoerd naar de wasser. Proceswater uit het biofilter wordt met mineralenconcentraat samengebracht in de buffertank. Tabel 3 vermeldt per luchtwasser het aantal dieren dat wordt bediend en een schatting van het maximale ventilatiedebiet.

Tabel 3 Geïnstalleerde ventilatiedebiet en aantal dieren waarvan de lucht wordt behandeld per luchtwasser op bedrijf $\mathrm{C}$.

\begin{tabular}{lllr}
\hline Luchtwasser & Dieren & Aantal & $\begin{array}{r}\text { Ventilatiedebiet } \\
\left(\mathrm{m}^{3} / \mathrm{h}\right)\end{array}$ \\
Chem. Wasser/biofilter & Biggen & 3500 & 87.500 \\
\hline & Vleesvarkens & 1200 & 50.500 \\
\hline
\end{tabular}




\subsubsection{Metingen en waarnemingen}

In de periode november/december 2012 werden gedurende 6 weken de volgende metingen en waarnemingen gedaan bij de drie luchtwas/indamp installaties:

- Volume van de dunne mestvloeistof en het eindproduct door middel van flowmeters en niveaumeting in de voorraadhouders.

- $\quad$ Samenstelling (N, PO4-, $\mathrm{K}, \mathrm{NH} 4+, \mathrm{NO} 2-, \mathrm{pH}$ ) van de dunne mestvloeistof en het eindproduct.

- Ammoniakconcentratie na de luchtwassers met behulp van Kitagawa ammoniak detectiebuisjes.

- $\quad$ Hoeveelheid van de gebruikte hulpstoffen; water door middel van watermeters, zuur en antischuimmiddel door middel van aflezen van niveau voorraadvaten.

- Ventilatiedebiet; inschatting op basis van niveau frequentieregelaars.

De ingaande vloeistof en de eindproducten werden wekelijks bemonsterd en geanalyseerd. Analyse werd uitgevoerd met een spectrofotometer (Hach, type DR 3900). De ammoniakconcentratie na de luchtwassers werd 2-wekelijks gemeten met Kitagawa ammoniak detectiebuisjes.

De hoeveelheid gebruikte hulpstoffen, het ventilatiedebiet en het energieverbruik werden wekelijks door de bedrijven geregistreerd (logboek).

\section{$2.2 \quad$ Meetfase}

\subsubsection{Meetlocatie}

In de tweede projectfase werden wederom metingen uitgevoerd aan de installatie op Bedrijf $A$, en wel aan de indamper bij de zeugenstal nadat deze enkele aanpassingen had ondergaan:

Zo werden de indampunits schuin geplaatst $\left(60^{\circ}\right)$ ter verbetering van het zelfreinigend vermogen. Bovendien werden de indampunits elk voorzien van een buffervat waaruit mestvloeistof werd gerecirculeerd (Figuur 4), waardoor het rondpompen van de vloeistof minder problemen opleverde. De mestvloeistof in deze fase bestond uit mineralenconcentraat dat werd verkregen na een 3-traps bewerking van zeugenmest:

(1) Scheiding door middel van een zeefbandpers.

(2) Verwijdering van organisch materiaal uit de dunne fractie door middel van dissolved air flotation.

(3) Indikken van de dunne vloeistof door middel van reverse osmosis (RO). Het RO-concentraat werd dus op het bedrijf zelf geproduceerd.

Het buffervat van indampunit 1 werd gevoed met mestvloeistof uit de mestbewerking. Buffervat 2 werd gevoed vanuit buffervat 1. Wanneer de mestvloeistof in buffervat 2 een bepaalde geleidbaarheid had bereikt werd een hoeveelheid ingedampte mestvloeistof naar de opslag voor het eindproduct gespuid. De luchtwasser bij de zeugenstal bestond evenals in de oriëntatiefase uit een chemische wasser waarin aangezuurd water circuleerde.

Het indamp/luchtwas systeem resulteerde in twee eindproducten:

(1) Ingedampte mestvloeistof met kalium als belangrijkste component.

(2) Spuiwater met verhoogd stikstofgehalte. 


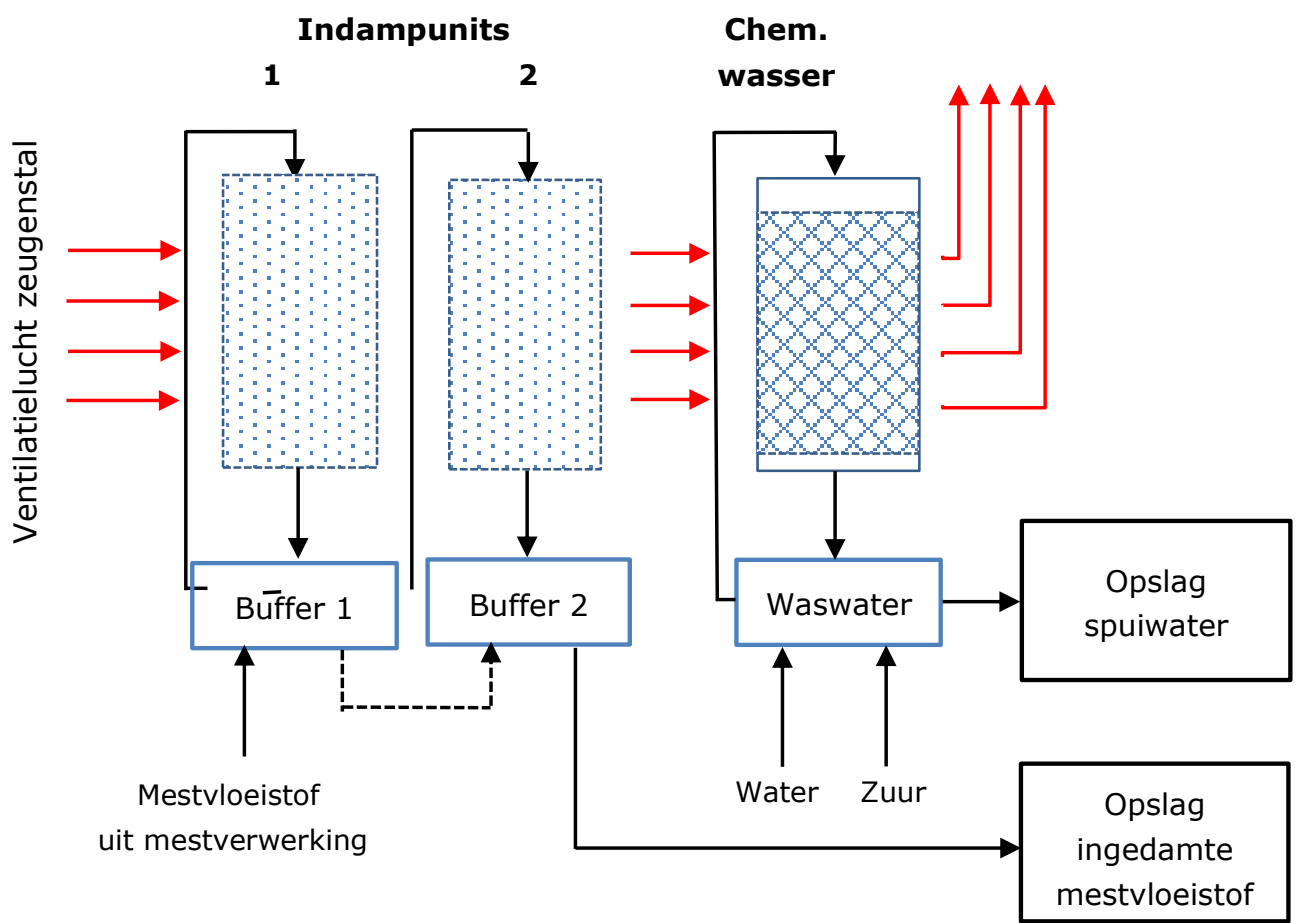

Figuur 4 Schematische weergave van het indamp/luchtwas systeem op bedrijf A in de meetfase.

\subsubsection{Meetprogramma}

In een tijdsbestek van 6 maanden (mei tot december 2015) werd op Bedrijf A 5 maal een serie metingen uitgevoerd aan de vloeistof- en luchtstromen. Op basis van de meetresultaten werd de indampcapaciteit bepaald en werd tevens vastgesteld of de chemische wasser met voorgeschakelde indamper de potentie heeft om de ammoniak- en geuremissies in de uitgaande luchtstroom niet te verhogen ten opzichte van een traditioneel systeem (stal met nageschakelde chemische wasser) en toch mestvloeistof te verdampen. De hoeveelheid verbruikte hulpstoffen werd wekelijks geregistreerd. Het meetprogramma in de meetfase is weergegeven in Tabel 4.

Tabel 4 Meetprogramma in de meetfase

\begin{tabular}{|c|c|c|}
\hline Wat & Eenheid & Hoe \\
\hline \multicolumn{3}{|l|}{ Processtromen: } \\
\hline $\begin{array}{l}\text { Volume ingaande dunne } \\
\text { mestvloeistof }\end{array}$ & $\mathrm{m}^{3}$ & Volumemeter in leiding naar buffer 1 \\
\hline Volume ingedampte mestvloeistof & $\mathrm{m}^{3}$ & $\begin{array}{l}\text { Volumemeter in leiding naar opslag eindproduct; } \\
\text { gewicht afgevoerde vrachten }\end{array}$ \\
\hline $\begin{array}{l}\text { Samenstelling ingaande dunne } \\
\text { mestvloeistof }\end{array}$ & $\begin{array}{l}\mathrm{N} \text {-tot, } \mathrm{NH}_{4}^{+}, \mathrm{P}, \mathrm{K}(\mathrm{g} / \mathrm{kg}) \\
\mathrm{pH}, \mathrm{EC}(\mathrm{mS} / \mathrm{cm})\end{array}$ & $\begin{array}{l}\text { Chemische analyse; monsterkraan op leiding naar } \\
\text { buffer } 1\end{array}$ \\
\hline Samenstelling inhoud buffertank & $\begin{array}{l}\mathrm{N} \text {-tot, } \mathrm{NH}_{4}^{+}, \mathrm{P}, \mathrm{K}(\mathrm{g} / \mathrm{kg}) \\
\mathrm{pH}, \mathrm{EC}(\mathrm{mS} / \mathrm{cm})\end{array}$ & Chemische analyse; monster uit buffer $1+2$ \\
\hline $\begin{array}{l}\text { Samenstelling ingedampte } \\
\text { mestvloeistof }\end{array}$ & $\begin{array}{l}\mathrm{N} \text {-tot, } \mathrm{NH}_{4}^{+}, \mathrm{P}, \mathrm{K}(\mathrm{g} / \mathrm{kg}) \\
\mathrm{pH}, \mathrm{EC}(\mathrm{mS} / \mathrm{cm})\end{array}$ & $\begin{array}{l}\text { Chemische analyse; monsterkraan op leiding naar } \\
\text { eindopslag/monster vracht }\end{array}$ \\
\hline $\begin{array}{l}\text { Samenstelling recirculatie water } \\
\text { luchtwassers (spuiwater) }\end{array}$ & $\begin{array}{l}\mathrm{N} \text {-tot, } \mathrm{NH}_{4}^{+}(\mathrm{g} / \mathrm{kg}) \\
\mathrm{pH}, \mathrm{EC}\end{array}$ & Monster uit buffer waswater \\
\hline \multicolumn{3}{|l|}{ Verbruik hulpstoffen: } \\
\hline Water & $\mathrm{m}^{3}$ & Aflezen watermeter \\
\hline Zuur & $\mathrm{kg}$ & Aflezen niveau voorraadvat \\
\hline Antischuim & $\mathrm{kg}$ & Aflezen niveau voorraadvat \\
\hline Energieverbruik & kWh & Aflezen elektriciteitsmeters \\
\hline \multicolumn{3}{|l|}{ Rendementsmetingen: } \\
\hline Ammoniak & $\mathrm{ppm}$ & $\begin{array}{l}24 \text { uursmeting; natchemisch; voor indamper } 1 \text {, na } \\
\text { indamper } 2 \text { en na wasser }\end{array}$ \\
\hline Geur & $\mathrm{OU}_{\mathrm{E}} / \mathrm{m}^{3}$ & $\begin{array}{l}2 \text { uursmeting; olfactometrisch; voor indamper } 1 \text {, } \\
\text { na indamper } 2 \text { en na wasser }\end{array}$ \\
\hline
\end{tabular}




\section{Resultaten}

\subsection{Oriëntatiefase}

\subsubsection{Bedrijf A}

Tabel 5 geeft een overzicht van de resultaten van de oriënterende metingen van bedrijf A.

Tabel 5 Meetprogramma in de meetfase

\begin{tabular}{|c|c|c|c|c|}
\hline \multirow[b]{2}{*}{ Volume } & & \multicolumn{2}{|c|}{$\begin{array}{l}\text { Dunne fractie } \\
\text { (vóór indamper) }\end{array}$} & Eindproduct \\
\hline & & $\mathrm{m}^{3}$ & 78 & 11 \\
\hline \multirow[t]{5}{*}{ Samenstelling } & $\mathrm{NH}_{4}^{+}$ & $\mathrm{mg} / \mathrm{l}$ & 3100 & 390 \\
\hline & $\mathrm{NO}_{2}^{-}$ & $\mathrm{mg} / \mathrm{l}$ & 0 & 8 \\
\hline & $\mathrm{PO}_{4}^{-}$ & $\mathrm{mg} / \mathrm{l}$ & 410 & 1700 \\
\hline & $\mathrm{K}^{+}$ & $\mathrm{mg} / \mathrm{l}$ & 7300 & 12400 \\
\hline & $\mathrm{pH}$ & & & 8,5 \\
\hline \multirow[t]{2}{*}{ Ammoniak concentratie } & Zeugenstal & ppm & 25 & 1 \\
\hline & Biggenstal & $\mathrm{ppm}$ & 22 & 0 \\
\hline \multirow[t]{3}{*}{ Hulpstoffen verbruik } & Zuur & I/dag & & 45 \\
\hline & Water & I/dag & & 315 \\
\hline & Antischuim & $\mathrm{kg}$ & & nihi \\
\hline Energie & & kWh & & n.g \\
\hline \multirow[t]{2}{*}{ Ventilatie debiet } & Zeugenstal & $\mathrm{m}^{3} / \mathrm{h}$ & & 132.000 \\
\hline & Biggenstal & $\mathrm{m}^{3} / \mathrm{h}$ & & 66.000 \\
\hline
\end{tabular}

n.g. = niet gemeten

Het indamp systeem op bedrijf $A$ heeft gedurende de meetperiode $2,5 \mathrm{~m}^{3}$ dunne fractie per dag behandeld. Dit komt overeen met de vooraf ingeschatte capaciteit van de installatie. De gemeten volumereductie bedroeg $67 \mathrm{~m}^{3}$ (78-11), oftewel $86 \%$. Dit komt overeen met een volumereductie van circa $800 \mathrm{~m}^{3}$ op jaarbasis.

Tijdens het indampproces is een groot deel van de $\mathrm{NH}_{4}{ }^{+}$uit de dunne fractie gestript; het eindproduct (ingedampte dunne fractie) bevat nog slechts 390 $\mathrm{mg} \mathrm{NH}_{4}{ }^{+} /$l. Het eindproduct bestaat voornamelijk uit kalium en fosfaat. Tevens werd een kleine hoeveelheid $\mathrm{NO}_{2}{ }^{-}$in het eindproduct gemeten.

De indamping van dunne fractie had geen negatieve invloed op de effectiviteit van de luchtwasser en daardoor ook niet op de ammoniakemissie. De gemeten $\mathrm{NH}_{3}$-concentratie van de uitgaande lucht na de luchtwassers was nagenoeg nul.

De verbruikte hoeveelheid zuur bedroeg gemiddeld 45 liter per dag tegenover circa 20 liter zonder indampers. Het extra zuurverbruik als gevolg van indamping bedroeg dus 25 liter per dag.

De hoeveelheid en de samenstelling van het spuiwater werd in deze fase niet gemeten.

Figuur 5 toont een flowschema met de belangrijkste kenmerken van de in- en uitgaande stromen van de indamper en wasser in de oriëntatiefase. 
Figuur 5 Flowschema van in- en uitgaande vloeistofstromen en lucht van de indamper/wasser van

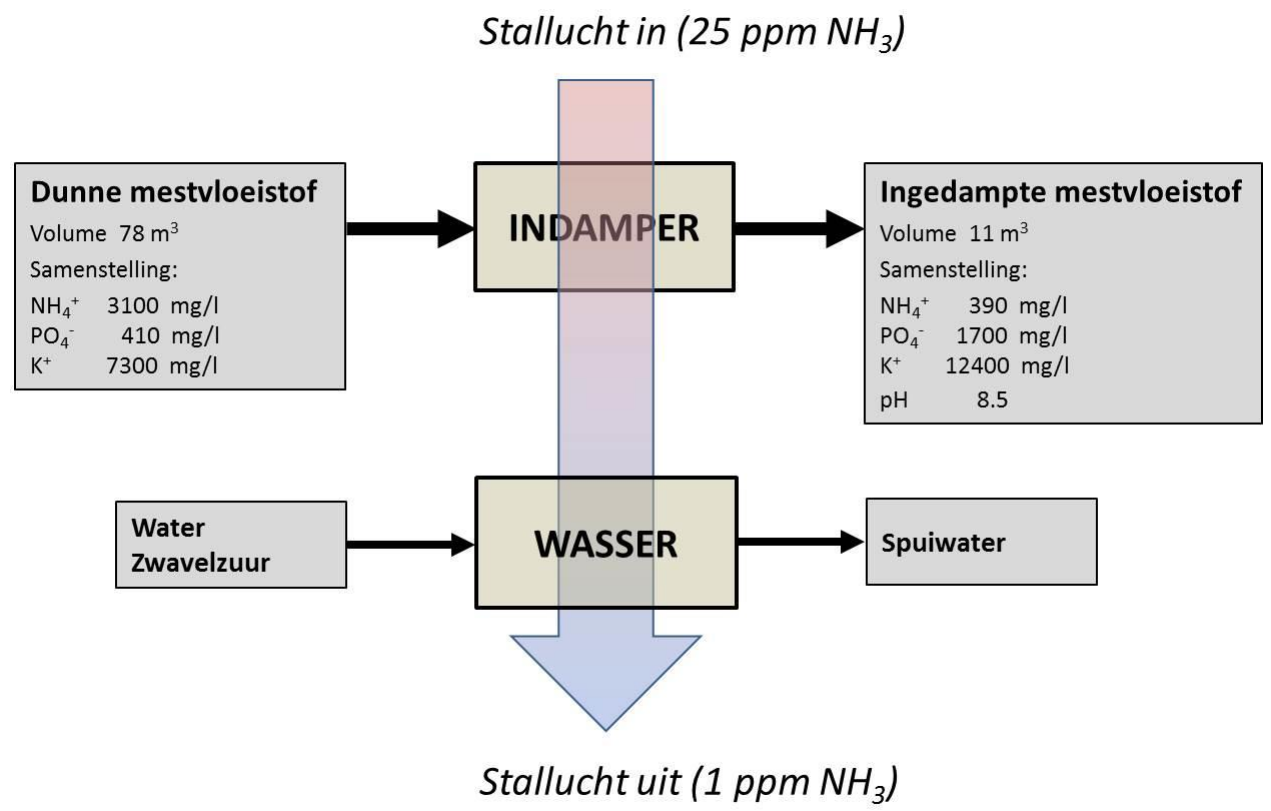

bedrijf $A$ in de oriëntatiefase.

\subsubsection{Bedrijf $\mathrm{B}$}

Tabel 6 geeft een overzicht van de resultaten van de oriënterende metingen van bedrijf B.

Tabel 6 Meetresultaten van bedrijf B in de oriëntatiefase

\begin{tabular}{|c|c|c|c|c|}
\hline \multirow[b]{2}{*}{ Volume } & & \multicolumn{2}{|c|}{ Dunne fractie } & \multirow{2}{*}{$\begin{array}{r}\text { Eindproduct } \\
42\end{array}$} \\
\hline & & $\mathbf{m}^{3}$ & 363 & \\
\hline \multirow[t]{5}{*}{ Samenstelling } & $\mathrm{NH}_{4}^{+}$ & $\mathrm{mg} / \mathrm{l}$ & 2900 & 75300 \\
\hline & $\mathrm{NO}_{2}^{-}$ & $\mathrm{mg} / \mathrm{l}$ & 0 & 0 \\
\hline & $\mathrm{PO}_{4}^{-}$ & $\mathrm{mg} / \mathrm{l}$ & 480 & 5900 \\
\hline & $\mathrm{K}^{+}$ & $\mathrm{mg} / \mathrm{l}$ & 7500 & 20760 \\
\hline & $\mathrm{pH}$ & & & 3,3 \\
\hline Ammoniak concentratie & & $\mathrm{ppm}$ & 17 & 0 \\
\hline \multirow[t]{3}{*}{ Hulpstoffen verbruik } & Zuur & I/dag & & 120 \\
\hline & Water & I/dag & & nihil \\
\hline & Antischuim & $\mathrm{kg}$ & & nihil \\
\hline Energie & & kWh & & n.g. \\
\hline Ventilatie debiet & Hele bedrijf & $\mathrm{m}^{3} / \mathrm{h}$ & & 240.000 \\
\hline
\end{tabular}

Op bedrijf B werd in de periode 1 november 2012 tot 11 januari 2013 (58 dagen) gemiddeld 6,3 $\mathrm{m}^{3}$ dunne fractie per dag behandeld. Hiermee werd ongeveer de helft van de capaciteit van de installatie benut. Aan de dunne fractie werd per dag $120 \mathrm{I}$ zuur toegevoegd. Totaal werd $370 \mathrm{~m}^{3}$ vloeistof (dunne fractie $+7 \mathrm{~m}^{3}$ zuur) behandeld. Hiervan resteerde $42 \mathrm{~m}^{3}$. De verdampte hoeveelheid water bedroeg derhalve $328 \mathrm{~m}^{3}$, wat overeenkomt met $2064 \mathrm{~m}^{3}$ per jaar. De gerealiseerde volumereductie bedraagt circa $20 \%$ van het totale mestvolume op het bedrijf.

Het eindproduct bevat een relatief hoog gehalte aan ammonium, te verklaren omdat ammonium uit de stallucht is ingevangen. Verder bevat het eindproduct aanzienlijke concentraties aan kalium en fosfaat. 
De behandeling van dunne fractie had geen negatieve invloed op de ammoniakemissie. De gemeten $\mathrm{NH}_{3}$-concentratie na de luchtwassers was nul.

De verbruikte hoeveelheid zuur bedroeg gemiddeld 120 liter per dag tegenover 40 liter zonder indampers. Het zuurverbruik dat aan de indamping moet worden toegeschreven bedroeg dus 80 liter per dag wat overeenkomt met circa 14 liter (= $26 \mathrm{~kg}$ ) per $\mathrm{m}^{3}$ ingedampte mestvloeistof. De kosten hiervan bedragen $26 * 0,25=6,50$ euro per $\mathrm{m}^{3}$.

Figuur 6 toont een flowschema met de belangrijkste kenmerken van de in- en uitgaande stromen van de indamper/wasser in de oriëntatiefase.

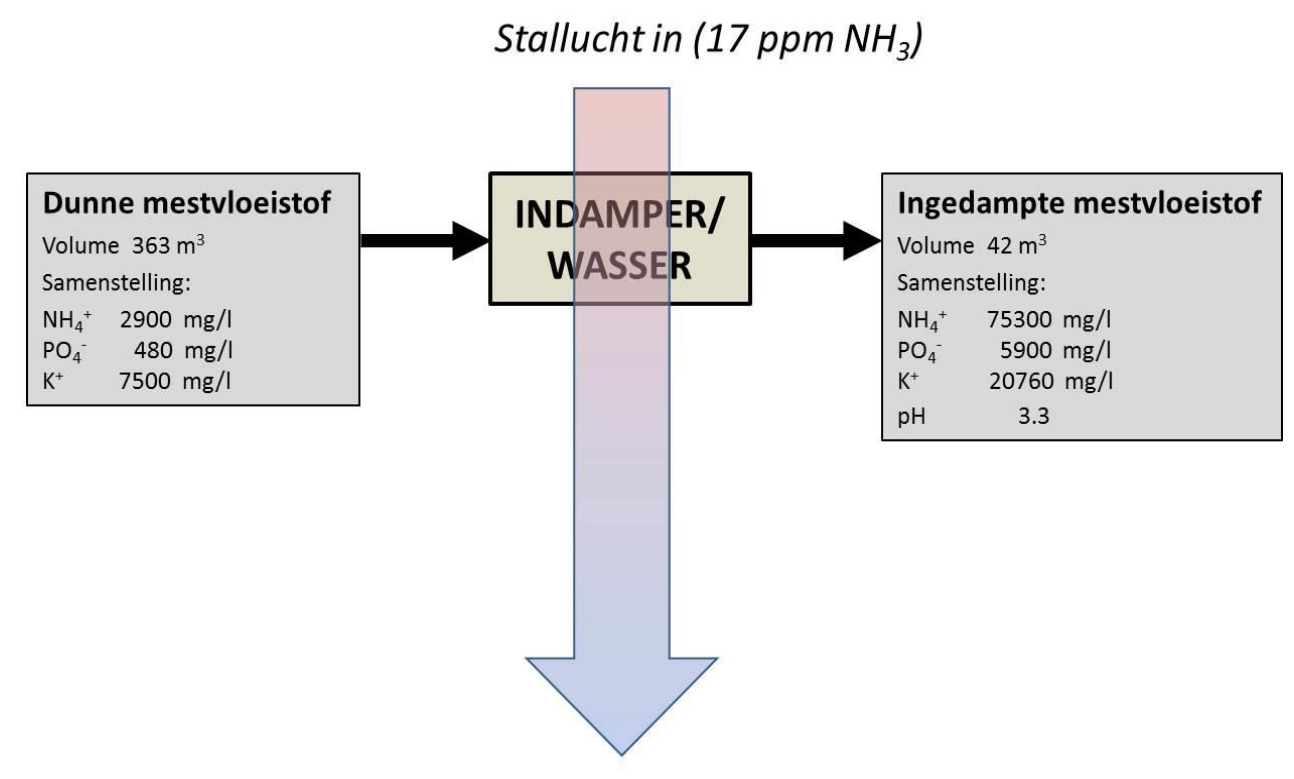

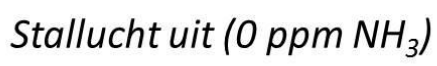

Figuur 6 Flowschema van in- en uitgaande vloeistofstromen en lucht van de indamper/wasser van bedrijf $B$ in de oriëntatiefase.

\section{Conclusie}

De combinatie van indamper en luchtwasser resulteerde over de meetperiode in een volumereductie van $20 \%$ van de totale mestproductie. Daar stond een zuurverbruik tegenover dat een factor drie hoger was dan zonder indamping. Er werden geen manieren gevonden om het zuurverbruik te verminderen. Naar het oordeel van de ondernemer woog het voordeel van de volumereductie niet op tegen de kosten van het verhoogde zuur- en energieverbruik dat aan de indamping moet worden toegeschreven.

\subsubsection{Bedrijf C}

Tabel 7 geeft een overzicht van de meetresultaten van bedrijf $\mathrm{C}$. 


\begin{tabular}{|c|c|c|c|c|}
\hline & & & $\begin{array}{l}\text { eralen } \\
\text { intraat }\end{array}$ & Eindproduct \\
\hline Volume & & $\mathrm{m}^{3}$ & 68 & 30 \\
\hline \multirow[t]{5}{*}{ Samenstelling eindproduct } & $\mathrm{NH}_{4}^{+}$ & $\mathrm{mg} / \mathrm{l}$ & 5900 & 2900 \\
\hline & $\mathrm{NO}_{2}^{-}$ & $\mathrm{mg} / \mathrm{l}$ & 0 & 12 \\
\hline & $\mathrm{PO}_{4}^{-}$ & $\mathrm{mg} / \mathrm{l}$ & 680 & 1600 \\
\hline & $\mathrm{K}^{+}$ & $\mathrm{mg} / \mathrm{l}$ & 14100 & 17200 \\
\hline & $\mathrm{pH}$ & & & 8,3 \\
\hline Ammoniak concentratie ${ }^{1}$ & & ppm & 28 & $0-20^{1}$ \\
\hline \multirow[t]{3}{*}{ Hulpstoffen verbruik } & Zuur & I/dag & 15 & 50 \\
\hline & Water & l/dag & & 410 \\
\hline & Antischuim & I/dag & & 0,57 \\
\hline Energie & & $\mathrm{kWh}$ & & n.g. \\
\hline Ventilatie debiet & & $\mathrm{m}^{3} / \mathrm{h}$ & & 195.000 \\
\hline
\end{tabular}

${ }^{1}$ Ammoniakconcentratie na indampen varieert van 0 - $20 \mathrm{ppm}$ over breedte van het biofilter

In de eerste twee weken van de meetperiode (tot 21 november 2012) waren er problemen met de zuurpomp waardoor te weinig zuur werd gedoseerd. Dit was van invloed op de werking van de luchtwasser en de samenstelling van het eindproduct.

De oriëntatiefase op bedrijf C liep van 15 november 2012 tot 19 december 2012 (34 dagen). In deze periode werd $68 \mathrm{~m}^{3}$ mineralenconcentraat behandeld, gemiddeld 2,0 $\mathrm{m}^{3}$ per dag. Hiermee werd ongeveer de helft van de capaciteit van de installatie benut. Het volume mineralenconcentraat verminderde van 68 tot $30 \mathrm{~m}^{3}$; een reductie van $63 \%$.

Tijdens het indampproces is ongeveer de helft van de ammonium uit de dunne fractie gestript. Zoals verwacht bevat het eindproduct (ingedampte mineralenconcentraat) hogere gehalten aan kalium en fosfaat dan het ruwe mineralenconcentraat. In het eindproduct werd een kleine hoeveelheid $\mathrm{NO}_{2}^{-}$aangetroffen.

De invloed van de behandeling op de ammoniakemissie is niet éénduidig. De gemeten $\mathrm{NH}_{3}{ }^{-}$ concentratie over de luchtwasser varieerde van nul tot $20 \mathrm{ppm}$.

De verbruikte hoeveelheid zuur bedroeg gemiddeld 50 liter per dag tegenover 15 liter zonder indampers.

Figuur 7 toont een flowschema met de belangrijkste kenmerken van de in- en uitgaande stromen van de indamper en wasser in oriëntatiefase.

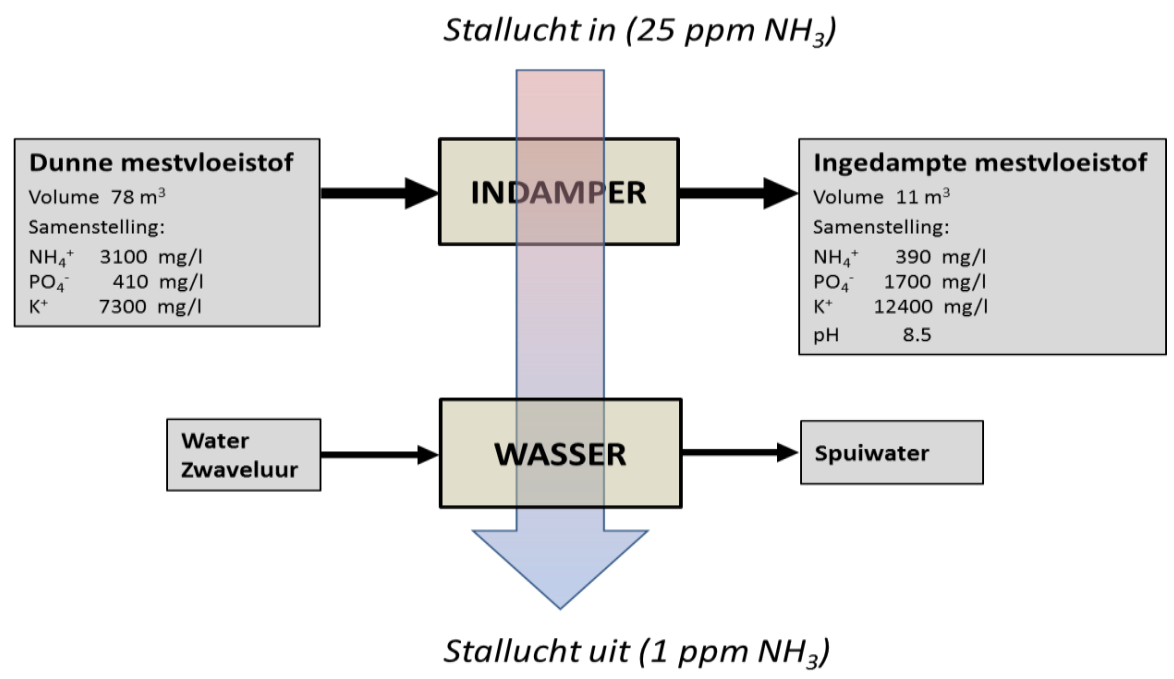

Figuur 7 Flowschema van in- en uitgaande vloeistofstromen en lucht van de indamper/wasser van bedrijf $C$ in de oriëntatiefase. 
Ondernemer heeft af moeten zien van deelname aan de meetfase omdat geen financiële ondersteuning is verleend (door leverancier van indamper/luchtwasser) voor vervanging van bestaande indamper.

\subsection{Meetfase}

\subsubsection{Volume en samenstelling processtromen}

Tabel 8 toont de volumes en de gemiddelde samenstelling van de dunne mestvloeistof en de ingedampte mestvloeistof van Bedrijf $A$ in de meetfase.

De meetfase is te verdelen in twee perioden. De eerste periode (tot 14 oktober 2015) kenmerkte zich door instabiliteit van het indampingsproces en de luchtbehandeling wat het gevolg was van suboptimale voorbehandeling van de dunne mestvloeistof. Tot begin oktober werd de dunne mestvloeistof verkregen via beluchting. Daarna werd omgekeerde osmose toegepast en was er sprake van een stabiel indampingsproces.

Tabel $8 \quad$ Volume en gemiddelde samenstelling van de dunne mestvloeistof en de ingedampte mestvloeistof.

\begin{tabular}{|c|c|c|c|c|}
\hline & & & $\begin{array}{l}\text { Dunne } \\
\text { mestvloeistof }\end{array}$ & $\begin{array}{l}\text { Ingedampte } \\
\text { mestvloeistof }\end{array}$ \\
\hline \multirow[t]{2}{*}{ Volume mestvloeistof } & $29 / 05-21 / 12$ & $\mathrm{~m}^{3}$ & 787 & 165 \\
\hline & $14 / 10-21 / 12$ & $\mathrm{~m}^{3}$ & 199 & 59 \\
\hline \multirow[t]{6}{*}{ Samenstelling $(\mathrm{gem})^{1}$} & $\mathrm{~N}$-totaal & $\mathrm{g} / \mathrm{kg}$ & 2140 & 1970 \\
\hline & $\mathrm{N}$-ammonium & $\mathrm{g} / \mathrm{kg}$ & 2110 & 1860 \\
\hline & P-totaal & $\mathrm{g} / \mathrm{kg}$ & 10 & 10 \\
\hline & K-totaal & $\mathrm{g} / \mathrm{kg}$ & 2180 & 6180 \\
\hline & $\mathrm{pH}$ & & 7,6 & 7,6 \\
\hline & EC & $\mathrm{mS} / \mathrm{cm}$ & 23,6 & 40,8 \\
\hline
\end{tabular}

\footnotetext{
${ }^{1}$ De gemiddelde samenstelling is berekend over de laatste 4 metingen in de periode $14 / 10-21 / 12$ (zie tabel 7)
}

In de hele meetfase, van 29 mei tot 21 december 2015, is totaal $787 \mathrm{~m}^{3}$ dunne mestvloeistof behandeld, wat neerkomt op $3,8 \mathrm{~m}^{3}$ per dag. De dunne mestvloeistof is ingedampt tot $165 \mathrm{~m}^{3}$, een volumevermindering van $622 \mathrm{~m}^{3}$, oftewel een reductie van $79 \%$. Per dag is gemiddeld $3,1 \mathrm{~m}^{3}$ mestvloeistof ingedampt, wat overeenkomt met een volumereductie van $1118 \mathrm{~m}^{3}$ op jaarbasis. In het tweede deel van de meetfase, van 14 oktober tot 21 december, is $199 \mathrm{~m}^{3}$ dunne mestvloeistof ingedampt tot $59 \mathrm{~m}^{3}$, een reductie van $140 \mathrm{~m}^{3}$, wat neerkomt op $70 \%$. In deze periode bedroeg de volumereductie $2,1 \mathrm{~m}^{3}$ per dag, wat overeenkomt met $751 \mathrm{~m}^{3}$ op jaarbasis.

De verhouding van het kaliumgehalte in de behandelde en de onbehandelde mestvloeistof, is een maat voor de indikking van de mestvloeistof; kalium vervluchtigt niet en zal dus geconcentreerder in het eindproduct aanwezig zijn. Gemiddeld bedraagt de verhouding $\mathrm{K}_{\text {behandeld }} / \mathrm{K}_{\text {onbehandeld }}=2,8 \mathrm{maar}$ hij varieert gedurende de meetperiode, zoals is weergegeven in Figuur 8. De figuur laat zien dat de indikking in de zomer hoger was dan in het najaar en de winter. Dit is te verklaren door de hogere temperatuur van de stallucht in de zomer, waardoor de lucht in de zomer een grotere wateropnamecapaciteit heeft. Daarnaast wordt 's zomers meer geventileerd.

De maximale indampcapaciteit op Bedrijf $A$ in de meetfase kan als volgt worden benaderd:

Hoeveelheid geventileerde lucht

Temperatuur stallucht

Maximale vochtgehalte stallucht

RV lucht vóór indamper

RV lucht na indamper

Maximale vochtopname

$\begin{array}{ll}1.200 .000 & \mathrm{~m}^{3} / \text { dag (50\% van capaciteit) } \\ 22 & { }^{\circ} \mathrm{C} \\ 20 & \mathrm{~g} / \mathrm{m}^{3} \\ 70 & \% \\ 100 & \%\end{array}$

ca. $6,6 \quad \mathrm{~m}^{3} / \mathrm{dag}$ 


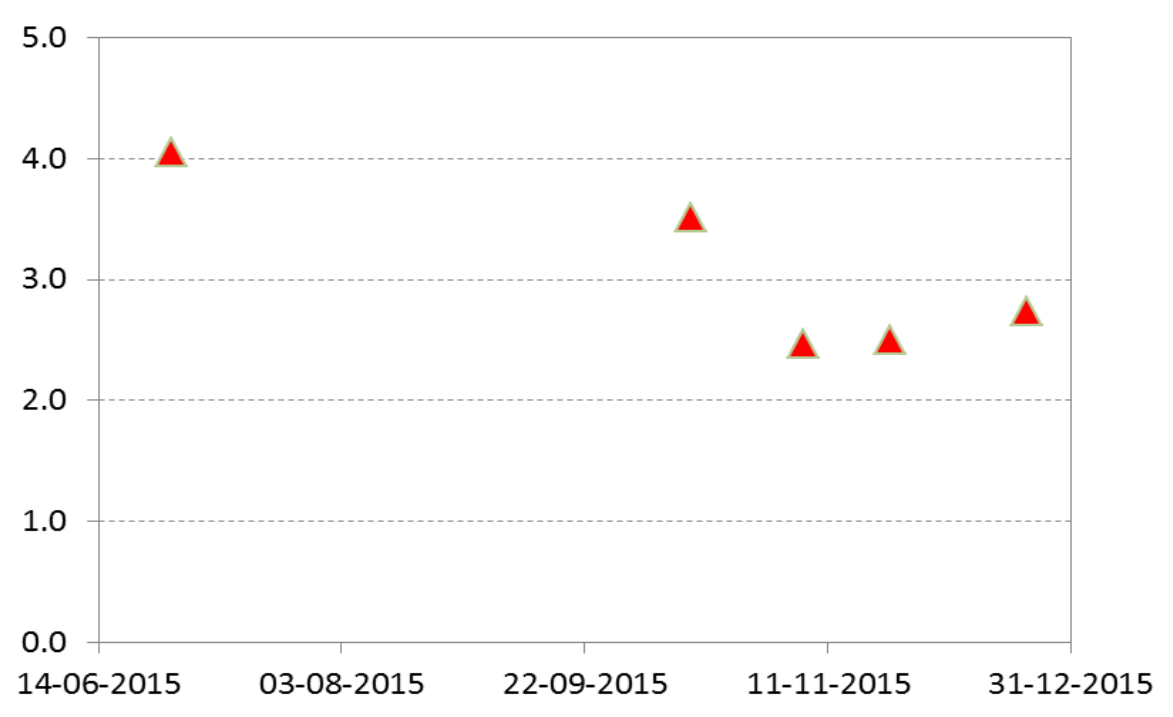

Figuur8 Schematische weergave van het indamp/luchtwas systeem op bedrijf A in de meetfase.

Het verschil in samenstelling tussen de ingaande mestvloeistof en de ingedampte mestvloeistof laat zien dat tijdens het indampproces een groot deel van de stikstof, die vrijwel volledig bestaat uit ammonium, uit de dunne mestvloeistof is gestript. De ingedampte mestvloeistof bevat een iets lager stikstofgehalte dan de onbehandelde mestvloeistof, wat betekent dat circa $80 \%$ van de aanwezige stikstof uit de dunne mestvloeistof is verwijderd en in de luchtstroom naar de luchtwasser is gevoerd.

Het fosforgehalte van de dunne mestvloeistof bedraagt slechts $10 \mathrm{mg} / \mathrm{l}$ en is tijdens het indampproces niet meetbaar toegenomen. Deze lage P-gehalten zitten in de buurt van de detectiegrens van de meetmethode. De EC-waarde, de stuurparameter van de indamper, van de ingedampte mestvloeistof komt gemiddeld overeen met de ingestelde waarde; ingedampte mestvloeistof werd batchgewijs afgevoerd op het moment dat een EC van $40 \mathrm{mS} / \mathrm{cm}$ werd bereikt.

De ingedampte mestvloeistof kan beschouwd worden als een kalimeststof met een relatief gering stikstofgehalte en vrijwel geen fosfaat.

Tabel 9 geeft per meting de samenstelling van de dunne mestvloeistof en de ingedampte mestvloeistof.

Tabel 9 Meetresultaten in projectfase 2; samenstelling van de dunne mestvloeistof en ingedampte mestvloeistof per meting.

\begin{tabular}{|c|c|c|c|c|c|c|c|c|c|c|}
\hline & \multicolumn{2}{|c|}{$\begin{array}{l}\text { Meting } 1 \\
\text { 29-06-2015 }\end{array}$} & \multicolumn{2}{|c|}{$\begin{array}{c}\text { Meting } 2 \\
14-10-2015 \\
\end{array}$} & \multicolumn{2}{|c|}{$\begin{array}{l}\text { Meting } 3 \\
5-11-2015 \\
\end{array}$} & \multicolumn{2}{|c|}{$\begin{array}{l}\text { Meting } 4 \\
23-11-2015 \\
\end{array}$} & \multicolumn{2}{|c|}{$\begin{array}{l}\text { Meting } 5 \\
\text { 21-12-2015 } \\
\end{array}$} \\
\hline & Dun & Ingedampt & Dun & Ingedampt & Dun & Ingedampt & Dun & Ingedampt & Dun & Ingedampt \\
\hline $\mathrm{N}$-totaal $[\mathrm{g} / \mathrm{kg}]$ & - & - & 2,28 & 1,94 & 2,13 & 1,97 & 2,15 & 1,95 & 2,00 & 2,01 \\
\hline $\mathrm{N}$-ammonium $[\mathrm{g} / \mathrm{kg}]$ & 2,88 & 0,11 & 2,19 & 1,60 & 2,10 & 1,82 & 2,10 & 1,85 & 2,06 & 1,17 \\
\hline P-totaal $[\mathrm{g} / \mathrm{kg}]$ & 0,09 & 0,21 & 0,01 & 0,02 & 0,01 & 0,01 & 0,01 & 0,01 & 0,01 & 0,01 \\
\hline K-totaal $[\mathrm{g} / \mathrm{kg}]$ & 3,41 & 13,8 & 2,51 & 8,81 & 2,10 & 5,19 & 2,20 & 5,51 & 1,91 & 5,23 \\
\hline $\mathrm{EC}[\mathrm{mS} / \mathrm{cm}]$ & - & 46,5 & 25,5 & 48,6 & 24,3 & 38,4 & 22,5 & 36,9 & 22,2 & 39,4 \\
\hline $\mathrm{pH}$ & - & - & 7,4 & 7,5 & 7,6 & 7,9 & 7,7 & 7,8 & 7,8 & 7,1 \\
\hline
\end{tabular}

Tabel 9 laat zien dat de dunne en de ingedampte mestvloeistof vanaf meting 2 op 14 oktober 2015 nauwelijks van samenstelling veranderen. Op 29 juni 2015 (meting 1) was de samenstelling afwijkend met hogere gehalten aan ammonium, P-totaal en K-totaal. Dit verschil in samenstelling is het gevolg van de gewijzigde voorbehandeling van de mestvloeistof vanaf begin oktober 2015 . 
Tot begin oktober werd de dunne mestvloeistof verkregen door de ruwe mest te scheiden en de dunne fractie te floteren en vervolgens te beluchten.

Het lukte (gedurende de zomer) niet hier een stabiel proces van te maken met als resultaat een eindproduct (mestvloeistof) met een variërend maar relatief hoog gehalte aan organisch materiaal, wat leidde tot haperingen in het indampproces door verstopping van pompen en vervuiling van het pakkingmateriaal van de indamper. Zonder deze instabiliteit zou de volumereductie groter zijn geweest. De samenstelling van de input is dus van groot belang voor een succesvolle werking van het systeem. Vanaf begin oktober werd de beluchter (beluchtingsschotels) uitsluitend gebruikt als roerder voor de dunne mestvloeistof.

In Tabel 10 wordt de samenstelling van het waswater per meting gegeven. Het verschil tussen beide metingen is zeer klein, wat duidt op een stabiel en goed gecontroleerd proces. De monstername van het waswater is vanaf meting 4 tegelijkertijd gebeurd met de emissiemetingen. Daarvóór werden enkel de processtromen van de mestverwerking bemonsterd en daar viel het waswater niet onder.

Tabel 10 Samenstelling van het waswater(=spuiwater) bij meting 4 en 5.

\begin{tabular}{lcrrr}
\hline & & Meting 4 & Meting 5 & Gemiddeld \\
\hline N-ammonium & 23-11-2015 & 21-12-2015 & \\
N-totaal & $\mathrm{g} / \mathrm{kg}$ & 47,2 & 49.6 & 48.4 \\
EC & $\mathrm{g} / \mathrm{kg}$ & 49,4 & 48.5 & 49,0 \\
$\mathrm{pH}$ & & 375 & 384 & 380 \\
\hline
\end{tabular}

Het spuiwater bevat in vergelijking met varkensdrijfmest en onbehandelde dunne mestvloeistof een hoog gehalte aan stikstof (circa factor 20 hoger) die volledig bestaat uit ammonium. Het kan als minerale $\mathrm{N}$-meststof worden gebruikt en kan als zodanig in plaats van kunstmest worden toegepast.

\subsubsection{Verbruik hulpstoffen}

In Tabel 11 wordt een overzicht gegeven van de verbruikte hoeveelheid water, zuur en antischuimmiddel van Bedrijf $A$ in de meetfase alsmede van het energieverbruik, dat aan het indamproces moet worden toegeschreven.

Tabel 11 Verbruik van hulpstoffen en energie.

\begin{tabular}{lrr}
\hline Zuur & l/dag & 54 \\
Water & l/dag & 1300 \\
Antischuimmiddel & $\mathrm{kg} / \mathrm{dag}$ & 1,0 \\
Energie & $\mathrm{kWh} / \mathrm{dag}$ & 54 \\
\hline
\end{tabular}

De verbruikte hoeveelheid zuur in de meetfase bedroeg gemiddeld 54 liter per dag tegenover 45 liter in de eerste meetfase. De grotere hoeveelheid behandelde mestvloeistof in de tweede meetfase en de daarmee gepaard gaande grotere ammoniakbelasting van de wasser is hier debet aan.

Het dagelijkse waterverbruik bedroeg in de meetfase $1300 \mathrm{I}$, wat nagenoeg gelijk is aan dat in de oriëntatiefase. We kunnen er van uitgaan dat in de wasser geen vloeistof verdampt, omdat de lucht uit de verdamper verzadigd is. Daardoor is minder waswater nodig, qua hoeveelheid gelijk aan de opgenomen hoeveelheid vocht uit de mestvloeistof. Daar staat tegenover de extra hoeveelheid waswater die nodig is voor opname van de uit de mestvloeistof gestripte ammoniak. Per saldo moet volgens berekening jaarlijks circa $50 \mathrm{~m}^{3}$ meer spuiwater worden afgevoerd dan zonder indamping. 
Het elektriciteitsverbruik van de indampinstallatie in de meetfase bedroeg gemiddeld 54 kwh per dag, het opgenomen vermogen van drie continu draaiende vloeistofpompen van $0,75 \mathrm{~kW}$ elk, ofwel bijna 14 kwh per behandelde kuub mestvloeistof.

\subsubsection{Ammoniak en geur}

Tabel 12 toont de resultaten van de ammoniak- en geurmetingen en de berekende rendementen.

Tabel 12 Ammoniak- en geurconcentraties en verwijderingsrendementen per meeting.

\begin{tabular}{|c|c|c|c|c|c|c|}
\hline & & & Stallucht & Na indamper & Na wasser & $\begin{array}{l}\text { Rendement } \\
\text { totaal }(\%)\end{array}$ \\
\hline \multirow[t]{5}{*}{ Ammoniak } & Meting 1 & $\mathrm{ppm}$ & 16,6 & 26,2 & 5,44 & 67 \\
\hline & Meting 2 & ppm & 13,1 & 30,0 & 3,95 & 70 \\
\hline & Meting 3 & $\mathrm{ppm}$ & 14,9 & 20,6 & 0,39 & 97 \\
\hline & Meting 4 & ppm & 17,6 & 22,2 & 0,40 & 98 \\
\hline & Meting 5 & ppm & 18,4 & 20,9 & 0,38 & 98 \\
\hline \multirow[t]{5}{*}{ Geur } & Meting 1 & $\mathrm{OU}_{\mathrm{E}} / \mathrm{m}^{3}$ & 1659 & 1353 & 935 & 44 \\
\hline & Meting 2 & $\mathrm{OU}_{\mathrm{E}} / \mathrm{m}^{3}$ & 1508 & 979 & 851 & 44 \\
\hline & Meting 3 & $\mathrm{OU}_{\mathrm{E}} / \mathrm{m}^{3}$ & n.g. & n.g. & n.g. & n.g. \\
\hline & Meting 4 & $\mathrm{OU}_{\mathrm{E}} / \mathrm{m}^{3}$ & 2993 & n.g. & 3539 & -18 \\
\hline & Meting 5 & $\mathrm{OU}_{\mathrm{E}} / \mathrm{m}^{3}$ & 1699 & 1402 & 1524 & 10 \\
\hline
\end{tabular}

Tabel 12 laat zien dat de ammoniakreductie bij de eerste twee metingen lager was dan de wettelijk vereiste $90 \%$, wat voor een groot deel te wijten is aan de te hoge $\mathrm{pH}$ van het waswater ten tijde van deze metingen. Ook de relatief hoge ammoniakconcentratie in de ingaande lucht (na indamper) heeft hierbij een rol gespeeld. Bij de laatste drie metingen, toen op een hogere zuurdosering werd overgegaan en de pH circa 2 bedroeg (zie Tabel 10), werd de vereiste ammoniakreductie ruimschoots gehaald. In de periode tussen de laatste drie metingen bedroeg de ammoniakconcentratie in de stallucht gemiddeld $17 \mathrm{ppm}$. Na de indamper is dit $21 \mathrm{ppm}$, een verhoging met 23\%.

Van de geuremissie werd op basis van een theoretische beschouwing verwacht dat deze door het voorschakelen van de indamper geen toename zou laten zien (zie Bijlage 1). De resultaten van de geurmetingen bevestigen deze verwachting; er vindt door het indampproces geen toename plaats van de geuremissie. 


\subsubsection{Flowschema}

Figuur 9 toont een flowschema met de belangrijkste kenmerken van de in- en uitgaande stromen van de indamper en wasser in de meetfase.

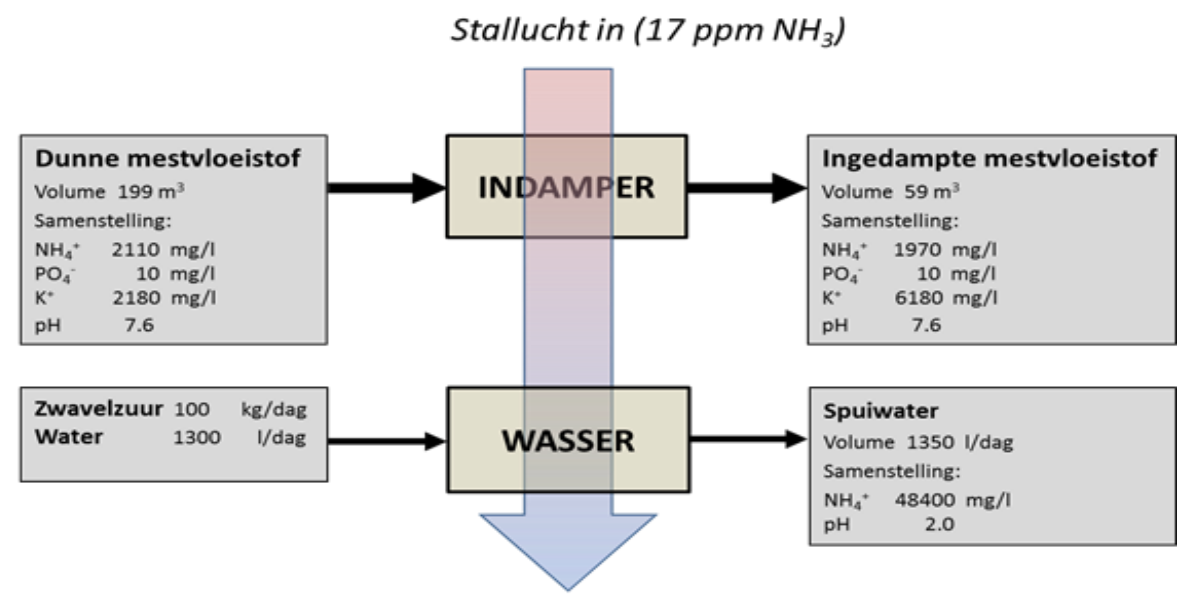

Stallucht uit (O ppm $\left.\mathrm{NH}_{3}\right)$

Figuur 9 Flowschema van in- en uitgaande vloeistofstromen en lucht van de indamper/wasser van Bedrijf $A$ in de meetfase.

\subsubsection{Economie}

Tabel 13 geeft een overzicht van de kosten van indampen van mestvloeistof in combinatie met een luchtwasser zoals dat op Bedrijf A in fase 2 werd toegepast. De kostenberekening sluit aan bij de berekeningswijze die in KWIN 2016-2017 (2016) wordt gevolgd voor de kosten van luchtwassers, uitgaande van een nieuw te bouwen complete installatie. Verder is uitgegaan van een gemiddelde indampcapaciteit van 3,3 m3 per dag (dit is 50\% van de maximale indampcapaciteit) oftewel een volumereductie van $1200 \mathrm{~m} 3$ per jaar. Opgemerkt wordt dat in de kostenberekening de kosten van voorbehandeling van de mest en de reeds aanwezige wassers niet zijn meegenomen.

Tabel 13 Kosten van indampen van mestvloeistof in combinatie met een luchtwasser zoals toegepast op Bedrijf $A$ in fase 2 (in Euro).

\begin{tabular}{lr}
\hline & $\mathcal{C}$ \\
\hline Investering & 55.000 \\
Rente, afschrijving en onderhoud & 10.000 \\
Operationele kosten: & 2.500 \\
$-\quad$ Elektriciteit (2 vloeistofpompen) & 600 \\
$-\quad$ Antischuimmiddel (300 liter per jaar) & 950 \\
$-\quad$ Extra zuur (3800 kg per jaar) & 14.050 \\
Totaal kosten per jaar & $\mathbf{1 1 , 7}$ \\
Kosten per $\mathbf{m}^{\mathbf{3}}$ ingedampte vloeistof &
\end{tabular}




\section{$4 \quad$ Discussie en conclusie}

\subsection{Discussie}

De oriënterende metingen aan drie praktijkinstallaties in fase 1 van het project, hebben aangetoond dat het inzetten van een luchtwasser voor het indikken van dunne mestvloeistoffen aanzienlijke volumereducties kan opleveren en dat dit niet ten koste hoeft te gaan van de emissiereducerende werking van de luchtwasser. Een systeem waarbij de indampunit en de luchtwasser in serie zijn geschakeld verdient de voorkeur boven een volledig geïntegreerd systeem waarbij de dunne mestvloeistof dient als wasvloeistof in de luchtwasser. In het laatste geval is de hoeveelheid zuur die nodig is om de zuurgraad van het waswater op het vereiste lage peil te houden het meervoudige van de hoeveelheid die nodig is bij gebruik van water als wasvloeistof. Deze extra hoeveelheid zuur is deels nodig in verband met de grotere buffercapaciteit van dunne mestvloeistof ten opzichte van die van water. Op Bedrijf B bedroeg de hoeveelheid zwavelzuur van de indamp/luchtwasinstallatie het drievoudige van de hoeveelheid zonder indamping, 120 liter per dag tegenover 40 liter per dag. De kosten van het extra zuurverbruik wogen niet op tegen de kostenbesparing van de volumereductie en de lagere bouwkosten van de installatie. Mogelijkheden om in de opzet van Bedrijf $B$ het zuurverbruik te verminderen werden niet gevonden.

In een systeem van gescheiden luchtwasser en indamper is eveneens meer zuur nodig dan in een systeem zonder indamper, maar uitsluitend om de uit de dunne mestvloeistof gestripte ammoniak te binden. Op Bedrijf $A$ bedroeg in fase 2 de verbruikte hoeveelheid zuur 54 I per dag tegenover 45 I per dag zonder indamping.

Dit onderzoek toont aan dat een luchtwasser met een voorgeschakelde indamper kan blijven functioneren met eenzelfde emissiereductie van ammoniak, als een luchtwasser zonder indamper. Er moet wel rekening worden gehouden met een hoger zuurverbruik om de hoeveelheid ammoniak die uit de vloeistof wordt gestript te binden. Het onderzoek heeft bovendien laten zien dat indampen gekoppeld aan een chemische wasser niet resulteert in een toename van de geuremissie. Daarmee zijn de resultaten van het onderzoek in overeenstemming met de verwachting op theoretische gronden, dat de emissie van ammoniak en geur niet hoeft toe te nemen als gevolg van indampen.

De resultaten van Bedrijf A laten zien dat gedurende de meetfase gemiddeld circa $3 \mathrm{~m} 3$ per dag mestvloeistof is ingedampt, waarmee het volume mineralenconcentraat dat jaarlijks op dit bedrijf uit zeugenmest wordt geproduceerd met ongeveer de helft kan worden gereduceerd; de productie aan zeugendrijfmest bedraagt $6600 \mathrm{~m} 3$ per jaar waaruit circa $2200 \mathrm{~m} 3$ mineralenconcentraat wordt gewonnen.

Omdat de indamper in de meetperiode niet op volle belasting heeft gedraaid, kan niet met zekerheid worden gezegd wat de maximale indampcapaciteit van deze installatie is. Wel kan worden gesteld dat deze globaal tussen 3 en 6 m3 per dag ligt. Bij een indampcapaciteit van 6 m3 per dag zou op Bedrijf A het geproduceerde mestvolume met een derde worden gereduceerd. In de zomermaanden wordt aanzienlijk meer vloeistof verdampt dan in de winter. In het algemeen zijn voor indampen met stallucht in de zomer de procesomstandigheden gunstiger dan in de winter, omdat in de zomer een grotere hoeveelheid ventilatielucht met hogere temperatuur beschikbaar is waarmee in de zomer een groter vochtopnamepotentieel beschikbaar is.

Kalium is het belangrijkste waardegevende bestanddeel van de ingedampte minerale mestvloeistof. Het gehalte aan kalium is een factor 3 hoger dan het gehalte aan stikstof en de vloeistof bevat nagenoeg geen fosfaat. De ingedampte mestvloeistof kan daarom beschouwd worden als een kaliummeststof. Het K-gehalte na indampen is een factor 3 hoger dan vóór indampen en is ongeveer gelijk aan het gehalte in zeugenmest. Met een gemiddelde $\mathrm{K}$-gehalte van circa $6 \mathrm{~g} / \mathrm{kg}$ vertegenwoordigt de ingedampte vloeistof een relatief geringe waarde; de prijs van kalikunstmest bedraagt ongeveer één euro per kilo zuivere $\mathrm{K}$. De vraag naar kali is de laatste jaren echter toegenomen als gevolg van verdere aanscherping van de gebruiksnormen voor dierlijke mest. 
In het algemeen is fosfaat de limiterende component waardoor bij sommige teelten naast een tekort aan stikstof ook een tekort aan kali optreedt. De afzetbaarheid van de ingedampte mestvloeistof zal hierdoor toenemen.

De economische beschouwing laat zien dat indampen van mestvloeistof tegen relatief geringe kosten mogelijk is. Afgezet tegen de huidige kosten van mestafzet, levert indampen in combinatie met een luchtwasser een kostenbesparing op van ongeveer 5 tot 10 euro per m 3 ingedampte mestvloeistof. Zoals opgemerkt zijn in de economische beschouwing de kosten van voorbehandeling niet meegerekend. Het is de vraag in hoeverre voorbehandeling aan het indampen moet worden toegerekend. Een vergaande bewerking van zeugendrijfmest inclusief omgekeerde osmose, zoals op Bedrijf A wordt toegepast, is niet nodig voor een goede werking van de indamper. In feite is het effect van omgekeerde osmose vergelijkbaar met dat van indampen, namelijk het indikken van dunne (minerale) mestvloeistof; de indikfactor bedraagt ongeveer 3 (Hoeksma et al, 2011). Indamping kan worden gezien als aanvullende stap waarmee de waarde van het minerale product na omgekeerde osmose wordt verhoogd. Mogelijk kunnen middels indamping de gehalten aan stikstof en kalium van de mestvloeistof zodanig worden verhoogd dat aan de EU-kwaliteitseisen voor minerale meststoffen kan worden voldaan, waardoor een product zou worden verkregen dat als 'kunstmest' kan worden verhandeld en boven de gebruiksnorm voor dierlijke mest kan worden aangewend.

Voor individuele varkensbedrijven ligt een opzet zonder omgekeerde osmose meer voor de hand, omdat omgekeerde osmose een relatief dure industriële techniek is die beter past bij mestbehandeling op regionaal niveau.

\subsection{Conclusie}

Indikken van dunne mestvloeistof in een indamper/luchtwasser combinatie, waarbij gebruik wordt gemaakt van geventileerde stallucht, kan een aanzienlijke volumereductie opleveren zonder dat dit ten koste gaat van de emissiereducerende werking van de luchtwasser voor wat betreft ammoniak en geur. Op een zeugenbedrijf kan het mestvolume minimaal met een derde worden gereduceerd.

De kosten van de volumereductie bedragen ongeveer 12 euro per $\mathrm{m}^{3}$. 


\section{$5 \quad$ Literatuur}

Hoeksma, P., F.E. de Buisonjé, P.A.I. Ehlert \& J. H. Horrevorts (2011). Mineralenconcentraten uit dierlijke mest. Monitoring in het kader van de pilots mineralenconcentraten. Wageningen UR Livestock Research, Rapport 481, 58p

Melse, R.W.; J.P.M. Ploegaert (2011). Sturing van spuiwaterafvoer bij een biologische luchtwasser door middel van meting van de elektrische geleidbaarheid. Rapport 435, Wageningen UR Livestock Research, Lelystad.

Infomil (2013). Technisch informatiedocument 'luchtwassystemen voor de veehouderij', Eisen aan en richtlijnen voor de uitvoering en het gebruik van luchtwassystemen in dierenverblijven. Versie 2.0 .

Wagenberg, A.V.; N. Verdoes; E. Vranken; D. Berckmans (1999). Waterverdamping uit dunne mest; resultaten van modelberekeningen. Proefverslag P 1.234. Praktijkonderzoek Varkenshouderij, Rosmalen.

Willers, H.C. (2000) Verdamping van varkensgier met ventilatielucht in Hercules Evaposcrubbers, Interne Rapportage Hercules Project Fase III - Deelonderzoek IMAG, 21 pp.

Willers, H.C; A.H.M. Veeken; R.W. Melse (2001) Beproeving van een testopstelling van de Hercules Evaposcrubber voor indikking van varkensgier en reductie van ammoniakemissie - Pilot experiments with the hercules Evaposcrubber for evaporation of pig urine and reduction of ammonia emission. Nota V 2001-78, augustus 2001. IMAG, Wageningen.

Willers, H.C.; R.W. Melse; N.W.M. Ogink (2003a) Concentration of urine from fatteners combined with ammonia removal by scrubbing exhaust air of a pig house. Proceedings of the Ninth International Symposium on Animal, Agricultural and Food Processing Wastes, October 12-15, 2003, Durham, North Carolina (NC), USA, pp. 584-589 (ASAE Publication Number 701P1203).

Willers, H.C.; P.J. Hobbs; N.W.M. Ogink (2003b).Odors from evaporation of acidified pig urine. In: Air Pollution from Agricultural Operations III : Proceedings of the 12-15 October 2003

Conference. Research Triangle Park : ASAE, 2004 - p. 318 - 322. 


\section{Bijlage 1 Verwachte emissies - theoretische beschouwing}

Auteur: Roland Melse

\section{Achtergrond}

Stallucht komt een luchtwasser in met een relatieve vochtigheid van circa $60 \%$ en een temperatuur van circa $20^{\circ} \mathrm{C}$ en verlaat de wasser met een relatieve vochtigheid in de buurt van $100 \%$. Als gevolg van de optredende adiabatische verdamping in de luchtwasser daalt de temperatuur van de lucht met circa $5^{\circ} \mathrm{C}$. De waterhoeveelheid in het systeem wordt telkens aangevuld met schoon water (leidingwater of bronwater). Hieruit is het idee ontstaan om via een luchtwasser dunne fracties uit mest in te dikken, met behoud van de werking van de luchtwasser. Dus in plaats van telkens schoon water toe te voegen, wordt dunne fractie afkomstig van mestscheiding aan het luchtwassysteem toegevoegd. Op deze manier vermindert het mestvolume van het bedrijf en nemen de mestafzetkosten af. Tegelijkertijd is het de bedoeling dat de luchtwasser normaal blijft functioneren, dat wil zeggen met eenzelfde emissiereductie van ammoniak en geen ongewenste bijeffecten zoals bijvoorbeeld toename van de geuremissie.

In dit hoofdstuk wordt op basis van de huidige kennis en beschikbare gegevens een inschatting gemaakt van de emissies van een dergelijk gecombineerd systeem.

\section{Invloed op emissies}

Algemeen

Tijdens het indampproces zal een deel van de vluchtige verbindingen (waar onder ammoniak en geurcomponenten) gestript kunnen worden uit de dunne mestfractie. De wassers kunnen als gevolg hiervan te maken krijgen met een hogere ammoniak- en geurbelasting. Dit zou in principe een verhoging van de emissies uit de luchtwasser kunnen veroorzaken. Onderstaand wordt voor de verschillende componenten nagegaan of een verandering van de emissie kan worden verwacht.

\section{Ammoniak}

Als gevolg van het indampen van mestvloeistof kan een deel van de in de vloeistof opgeloste ammoniak in de lucht terechtkomen ('strippen'). De luchtwasser wordt dan zwaarder belast met ammoniak en dit zou kunnen leiden tot een hogere ammoniakconcentratie in de uitgaande lucht van de wasser, met als gevolg hiervan een verhoging van de emissie.

Het 'Technisch informatiedocument luchtwassystemen voor de veehouderij' (Infomil, 2013) zegt het volgende over chemische luchtwassers die zwaarder met ammoniak belast worden:

"Uit theoretisch rekenwerk van Agrotechnology \& Food Innovations volgt dat een verhoging van de ammoniakconcentratie nauwelijks of geen invloed heeft op de capaciteit van het chemische luchtwassysteem (de omvang van het filterpakket). Voorwaarde is wel dat de procesomstandigheden goed moeten zijn (voldoende lage $\mathrm{pH}$, goed werkende regelingen en voldoende toe- en afvoer van waswater). De bepalende factor voor de ammoniakverwijdering is de verblijftijd in de wasser, of de verhouding van het luchtdebiet en de omvang van de wasser".

De reden voor het feit dat een verhoging van de ingaande ammoniakconcentratie weinig invloed heeft op het nageschakelde chemisch luchtwassysteem, is dat het $\mathrm{NH}_{3} / \mathrm{NH}_{4}{ }^{+}$evenwicht erg ver naar de $\mathrm{NH}_{4}{ }^{+}$kant ligt bij zure waswatercondities, d.w.z. $\mathrm{pH}=4$ of lager.

Daarnaast is laboratorium- en pilot-onderzoek (Willers, 2000; Willers et al., 2001, 2003a) uitgevoerd naar een combinatiesysteem van indamping en luchtwassing, wat qua ontwerp vergelijkbaar is met het systeem zoals bij bedrijf $B$. In het onderzoek was overigens geen sprake van indamping van mestvloeistof afkomstig uit scheiding van drijfmest, maar van indamping van gier die afkomstig was van een bolle-bandsysteem onder de roostervloer ('primaire scheiding'). Aangezien (bijna) alle ammoniak afkomstig is uit de urine, wordt er voor wat betreft de emissie van ammoniak geen verschil verwacht tussen de systemen. 
Uit het onderzoek van Willers (2000) en Willers et al. (2001, 2003a) bleek dat, ondanks de hogere ammoniakbelasting van de luchtwasser, normale ammoniakverwijderingsrendementen werden gehaald.

De ammoniakconcentratie van de lucht die het systeem verliet, was vergelijkbaar met een reguliere chemische luchtwasser zonder indamping van mestvloeistof. Naar verwachting zal dit ook gelden voor een systeem waarbij indamping en luchtwassing wel in een verschillende unit plaatsvinden (ontwerp bedrijf $A$ en $C$ ).

Op basis van het bovenstaande wordt geconcludeerd dat het combineren van indampen van mestvloeistof en chemische/combi-luchtwassing niet hoeft te leiden tot een verhoging van de ammoniakemissie.

\section{$\underline{\text { Geur }}$}

Ook voor geurcomponenten geldt dat het denkbaar is dat een deel van de in de mest opgeloste geurstoffen in de lucht terechtkomen wanneer de mestvloeistof wordt ingedampt.

Het is moeilijk om een theoretische inschatting te maken van het effect van indampen op de geuremissie, omdat 'geur' is opgebouwd uit een groot aantal componenten met verschillende fysisch/chemische eigenschappen in verschillende concentraties.

Wel is er enig experimenteel werk bekend. In het hierboven reeds genoemde laboratorium- en pilotonderzoek naar luchtwassing en indamping van varkensgier (afkomstig van het 'bolle-bandsysteem') zijn behalve ammoniakmetingen ook geurmetingen uitgevoerd (Willers, 2000; Willers et al., 2001, 2003b). Uit dit onderzoek bleek dat de geurconcentratie van de uitgaande lucht van het verdampingsluchtwassysteem in het algemeen niet hoger was dan van de ingaande lucht. Hierbij moet aangetekend worden, dat een mestvloeistof afkomstig van scheiding van drijfmest (zoals het geval is bij bedrijf $A$, B en C) mogelijk een hoge concentratie geurcomponenten zal bevatten dan de gier die door Willers (2000) en Willers et al. (2001) is gebruikt in het onderzoek. Wel is het zo dat een oriënterende geurmeting die in augustus 2014 is uitgevoerd bij bedrijf A er op wijst dat indamping van mestvloeistof gevolgd door luchtwassing niet hoeft te leiden tot een significante toename van de geuremissie; maar het betreft hier een enkele meting waaruit geen harde conclusie is te trekken. Op basis van het bovenstaande wordt geconcludeerd dat het combineren van indampen van mestvloeistof en chemische/combi-luchtwassing, niet hoeft te leiden tot een verhoging van de geuremissie. Aanvullend onderzoek naar de geuremissie wordt echter nodig geacht.

\section{Overige componenten}

Wat betreft de emissie van fijnstof en broeikasgassen (methaan en lachgas) wordt opgemerkt dat het onwaarschijnlijk is dat de toepassing van een gecombineerd indamp-luchtwassysteem zal leiden tot een verandering (toename of afname) van de emissies.

\section{Conclusie}

Op basis van theoretische overwegingen en beschikbare resultaten van onderzoek wordt geconcludeerd dat toepassing van een gecombineerd indamp-luchtwassysteem, zoals toegepast bij bedrijf $A, B$ en $C$, niet hoeft te leiden tot een toename van de ammoniak- of geuremissie. Ook voor de emissie van overige componenten (fijnstof en broeikasgassen (methaan en lachgas)) is het onwaarschijnlijk dat het systeem invloed zal hebben op de emissie. 




Wageningen Livestock Research Postbus 338

$6700 \mathrm{AH}$ Wageningen

T 0317483953

E info.livestockresearch@wur.nl www.wur.nl/livestock-research



Wageningen Livestock Research ontwikkelt kennis voor een zorgvuldige en renderende veehouderij, vertaalt deze naar praktijkgerichte oplossingen en innovaties, en zorgt voor doorstroming van deze kennis. Onze wetenschappelijke kennis op het gebied van veehouderijsystemen en van voeding, genetica, welzijn en milieu-impact van landbouwhuisdieren integreren we, samen met onze klanten, tot veehouderijconcepten voor de $21 \mathrm{e}$ eeuw.

De missie van Wageningen University \& Research is 'To explore the potential of nature to improve the quality of life'. Binnen Wageningen UR bundelen 9 gespecialiseerde onderzoeksinstituten van stichting DLO en Wageningen University hun krachten om bij te dragen aan de oplossing van belangrijke vragen in het domein van gezonde voeding en leefomgeving. Met ongeveer 30 vestigingen, 6.000 medewerkers en 10.000 studenten behoort Wageningen UR wereldwijd tot de aansprekende kennisinstellingen binnen haar domein. De integrale benadering van de vraagstukken en de samenwerking tussen verschillende disciplines vormen het hart van de unieke Wageningen aanpak. 